\title{
Isolation and Activity Determination of Enzyme Phosphatase Secreted by Aspergillus niger
}

\author{
Tafadzwa Zharare, Rumbidzai Mangoyi* \\ Department of Biochemistry, University of Zimbabwe \\ * Corresponding author email: rrumbie.2000@gmail.com
}

Received: 04 October 2019 / Revised: 30 October 2019 / Accepted: 10 November 2019 / Published: 16 November 2019

\begin{abstract}
The use of enzymes on industrial scale saves a lot of energy and avoids pollution, thus holding a promise for green and economically sustainable alternative strategies in industrial transformations. Generally, the fungi Aspergillus niger secretes enzymes which can be used in different industries. Thus, coming up with these enzymes in large amounts will definitely result in reduced costs encountered in importing them for industrial use. This study focussed on isolation and activity determination of an enzyme phosphatase secreted by Aspergillus niger. This enzyme can be of great importance in molecular biology industries, particularly for recombinant DNA technology. For this study, pure cultures of Aspergillus niger were used. Aspergillus niger was resuscitated on potato dextrose agar and then subcultured in Adam's medium, a medium specific for the production of phosphatase. Cells were centrifuged and the filtrate was collected whilst the residue was discarded. The filtrate was expected to contain the crude enzyme phosphatase since Aspergillus niger secretes the extracellular enzyme into the medium. Disodium phenyl phosphate was used as a substrate for the determination of the phosphatase activity. The enzyme activity was determined spectrophotometrically by reading absorbance of phenol formed in the presence of enzyme and the substrate. The concentration of phenol liberated was then used to calculate the enzyme activity expressed in King Armstrong Units (KAU). Further work on enzyme activity determination was done by varying enzyme and substrate concentrations. Results showed that the isolated alkaline phosphatase had activity of $4.0 \mathrm{KAU}$ and $4.5 \mathrm{KAU}$ at $25^{\circ} \mathrm{C}$ and $37^{\circ} \mathrm{C}$ respectively. Acidic phosphatase had activity of $5 \mathrm{KAU}$ and $7 \mathrm{KAU}$ at $25^{\circ} \mathrm{C}$ and $37^{\circ} \mathrm{C}$ respectively. Rate of activity increased upon increasing enzyme concentration and substrate. Thus, Aspergillus niger produces the enzyme phosphatase, however, there is need to induce the production of these enzymes for industrial use.

Keywords: Activity, acidic phosphatase, alkaline phosphatase, Aspergillus niger, enzymes, industrial use.
\end{abstract}

\section{Introduction}

Enzymes are now being used as an alternative in catalyzing variety of reactions in different industries. Generally, enzymes carry out their chemical reactions selectively, rapidly and efficiently whilst providing environmentally friendly alternatives in the industry.

Advancements in areas such as genetics and protein engineering are offering a new era for enzyme applications in industrial processes which has resulted in the development of new products and improvement of products that were already available [1]. There are over 3000 different enzymes in existence but only about 170 enzymes are being used for commercial purposes [2]. Some enzymes such as phosphatases had received less attention due to difficulties in obtaining well defined substrates to help in their study. Phosphatases are enzymes which catalyze the hydrolytic cleavage of Oxygen - Phosphate (O-P) bonds of phosphoric esters liberating inorganic phosphate. They are mostly used in biomedical research and also in industry because of their high resistance to denaturation, inactivation and degradation [3]. In biochemistry, phosphatases play diverse and important roles for example in RNA/DNA replication, signal transduction, phospholipid metabolism, protein 
Isolation and Activity Determination of Enzyme Phosphatase Secreted by Aspergillus niger

activation and deactivation, transcription control and energy storage as well as cell transformation. Phosphatases have two major classes called alkaline phosphatases (ALP) and acidic phosphatases (ACP). The ALP (E.C 3.1.3.1) is responsible for the removal of phosphate groups from biomolecules such as nucleotides, DNA, proteins and alkaloids, hence have many applications in different fields such as immunology, dairy technology and diagnostics [4]. Acidic Phosphatase (ACP, E.C. 3.1.3.2) also catalyse the hydrolysis of phosphor-monoester bonds liberating inorganic phosphate and an alcohol. In nature fungal ACPs have a role in plant-fungus symbiotic relationships where they mobilize phosphate for the plant [5]. Phosphatases are widely distributed in nature from prokaryotes to higher eukaryotes excluding some higher plants. Various microorganisms including $A$. niger secrete phosphatases in a phosphate mediated repression process [6]. High phosphatase production is only observed under limiting amounts of phosphate in culture media. Thus, this project focused on isolation of phosphatases from Aspergillus niger for use in different industries.

\section{Materials and Methods}

\subsection{Growing Aspergillus niger}

Stock culture of $A$. niger was prepared from pure strain, which was provided by $\mathrm{Mr}$ Ashley from the Biological sciences department, University of Zimbabwe. A colon of Aspergillus niger was streaked on potato dextrose agar and incubated for 7 days at $37{ }^{\circ} \mathrm{C}$. The fungus was then subcultured for 5 days at $37^{\circ} \mathrm{C}$ and $150 \mathrm{rpm}$ in Adam's medium, which induces the secretion of extracellular phosphatases. The cells were then centrifuged at $3000 \mathrm{rpm}$ for 10 minutes. The pellet was discarded, and the supernatant was collected since it contained the secreted phosphatase and stored at $4{ }^{\circ} \mathrm{C}$ until use.

\subsection{Phosphatase activity determination}

The supernatant was used as the enzyme since it was assumed to contain phosphatase and disodium phenyl phosphate was used as a substrate for the determination of phosphatases
(ALP and ACP) activity. The enzyme activity was determined spectrophotometrically at $600 \mathrm{~nm}$ by reading absorbance of phenol liberated in the presence of enzyme and the substrate. For the assay, an enzyme sample $(200 \mu \mathrm{l})$ was diluted with $2000 \mu \mathrm{l}$ buffer $(0.1 \mathrm{M}$ citric acid buffer $\mathrm{pH} 4.9$ for ACP and 0.1 M Sodium carbonate/Sodium bicarbonate buffer $\mathrm{pH} 10$ for ALP). For each enzyme, the diluted samples were placed in tubes labeled $\mathrm{A}$ and $\mathrm{B}$. Tube $\mathrm{A}$ was left at room temperature and tube $\mathrm{B}$ was incubated at $37^{\circ} \mathrm{C}$. After 3 minutes, $2000 \mu 10.01$ M Disodium phenyl phosphate substrate was added to both tubes and tube $\mathrm{B}$ was left to incubate at $37^{\circ} \mathrm{C}$ for 15 minutes and 60 minutes for ALP and ACP respectively, whilst tube A was left at room temperature. After the incubation time, $1800 \mu \mathrm{l}$ of $0.5 \mathrm{~N}$ FolinCiocalteu's (F-C) reagent was added to both tubes, and both $\mathrm{A}$ and $\mathrm{B}$ tubes were left to incubate at $37{ }^{\circ} \mathrm{C}$ for 5 minutes. Colour development was carried out by adding $2000 \mu \mathrm{l}$ of $15 \%$ sodium carbonate to the tubes which were then left for 10 minutes. The samples were diluted with $4000 \mu \mathrm{l}$ of distilled water and the absorbance was read at $600 \mathrm{~nm}$. The concentration of phenol liberated was used to calculate the enzyme activity expressed in King Armstrong Units (KAU); where $1 \mathrm{KAU}=1 \mathrm{mg}$ of phenol liberated by $100 \mathrm{ml}$ enzyme in 15 minutes at $37{ }^{\circ} \mathrm{C}$. Further work on enzyme activity determination was done by varying temperature, varying enzyme concentration and varying substrate concentration.

\subsection{Standard Curve}

The stock standard solution was prepared by dissolving phenol in $500 \mathrm{ml}$ of distilled water. The working standard solution was then prepared by diluting the stock solution X3 with distilled water. A set of 9 test tubes were set up and varying concentrations of phenol $(0 \mathrm{ml}, 0.5 \mathrm{ml}$, $1.0 \mathrm{ml}, 1.5 \mathrm{ml}, 2.0 \mathrm{ml}, 2.5 \mathrm{ml}, 3.0 \mathrm{ml}, 3.5 \mathrm{ml}, 4.0$ $\mathrm{ml}$ ) were added, and distilled water was added to make up to $4 \mathrm{ml}$ in each tube. A volume of 1.8 $\mathrm{ml}$ of $0.5 \mathrm{~N}$ F-C reagent was added to each tube and the tubes were left to incubate at $37^{\circ} \mathrm{C}$ f or 5 minutes. Colour development was carried out by adding $2 \mathrm{ml}$ of $15 \%$ sodium carbonate to the tubes which were then left to develop for 10 
Zharare et al., Int. Ann. Sci.; Vol. 9, Issue 1, pp: 41-45, 2020

minutes. Samples were then diluted with $4 \mathrm{ml}$ of water and the absorbance was read at $600 \mathrm{~nm}$.

\subsection{Data Analysis}

Statistical Package for the Social Sciences (SPSS) was used for the analysis of the data. The package provides a user-friendly interface for statistical analysis.

\section{Results}

\subsection{ALP and ACP enzyme activity determination}

The absorbance of phenol produced when enzymes ALP and ACP were incubated in the presence of the substrate was measured spectrophotometrically and the concentration of phenol liberated was interpolated from the standard curve. Using the concentrations obtained, the rate of activity of each enzyme was then calculated and expressed in King Armstrong Units (KAU). Results show that both enzymes were successfully isolated as there was an increase in the rate of product formation after addition of
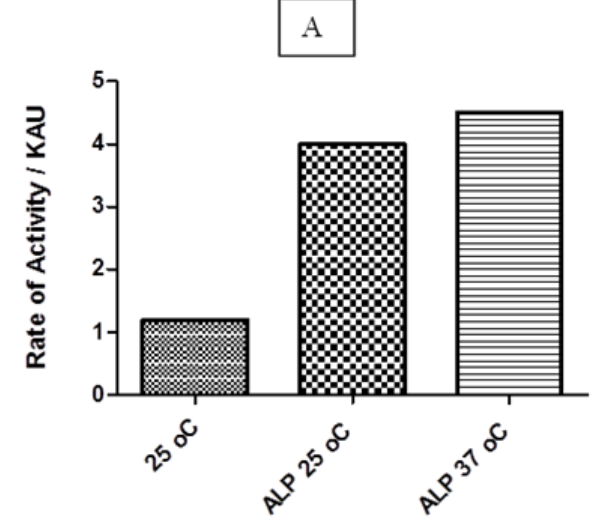

the enzyme. Increase in product formation is a result of increased rate of enzyme activity as shown in figure 1 . There was increase in the rate of enzyme activity at an optimum temperature of $37^{\circ} \mathrm{C}$ for both enzymes, as compared to $25^{\circ} \mathrm{C}$ and in the absence of the enzyme. The rate of product formation in the absence of enzyme was found to be $1.4 \mathrm{KAU}$ and in the presence of ALP, the rate of activity at $25^{\circ} \mathrm{C}$ and $37^{\circ} \mathrm{C}$ was found to be $4.0 \mathrm{KAU}$ and $4.5 \mathrm{KAU}$ respectively. In the presence of ACP, the rate of activity at $25^{\circ} \mathrm{C}$ was found to be $5.0 \mathrm{KAU}$ and was found to be 7.0 $\mathrm{KAU}$ at $37^{\circ} \mathrm{C}$.

\subsection{Effects of enzyme concentration}

The rate of activity of both enzymes was then investigated by varying the enzyme concentration and results are shown in figure 2. There was increase in rate of activity as the enzyme concentration increased and greatest increase was observed when the enzymes were incubated at their optimum temperature of $37^{\circ} \mathrm{C}$.

Figure 1: Rate of activity in the presence and absence of $A L P(A)$ and $A C P(B)$ measured in $K A U$.
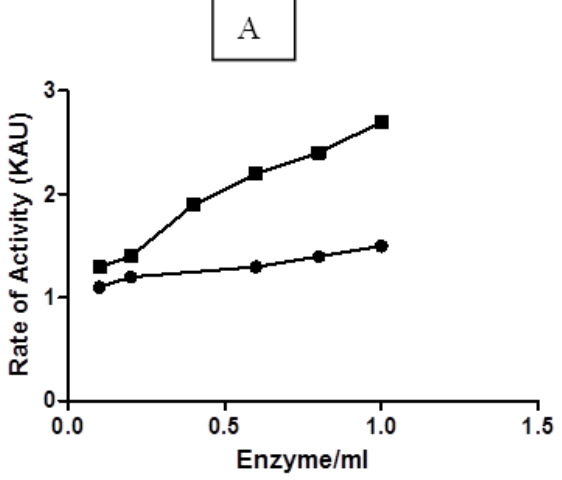

$\mathrm{B}$

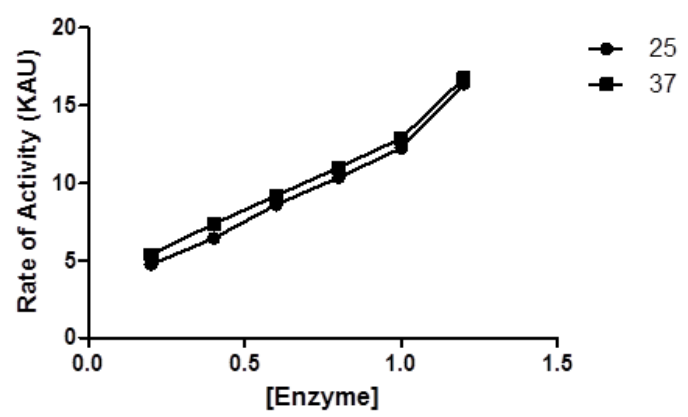

Figure 2: Rate of activity of $A L P(A)$ and $A C P(B)$ at increasing enzyme concentration and temperatures $25^{\circ} \mathrm{C}$ and $37^{\circ} \mathrm{C}$. 
A

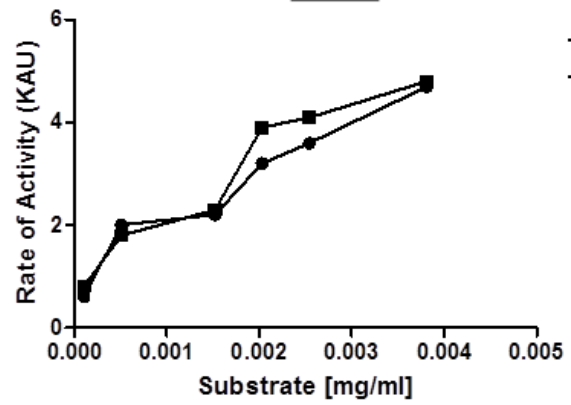

$\mathrm{B}$

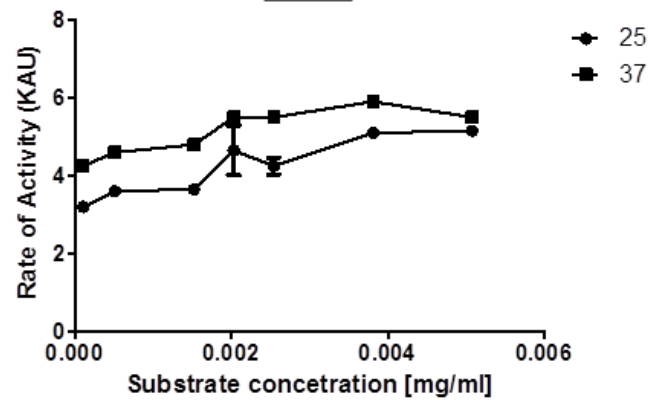

Figure 3: Rate of activity of $A L P(A)$ and $A C P(B)$

at increasing substrate concentration and temperatures $25^{\circ} \mathrm{C}$ and $37^{\circ} \mathrm{C}$.

\subsection{Effects of substrate concentration}

The rate of activity of both enzymes was then investigated by varying the substrate concentration and results are shown in figure 3 . There was increase in rate of activity as the substrate concentration increased.

\section{Discussion}

The isoenzymes ALP and ACP are known to hydrolyse the substrate disodium phenylphosphate to yield phenol and inorganic phosphate at different $\mathrm{pH}$. The $\mathrm{pH}$ optima of ACP are 4.8 and that of ALP is 9.0 [7]. The enzyme activity determination results in this study showed that both ACP and ALP were secreted by $A$. niger into Adam's medium and were successfully isolated. This is because when the filtrate, the solution which enzymes were expected to be, was incubated in the presence of the substrate disodium phenylphosphate, the rate of phenol formation increased as compared to when incubated in the absence of the filtrate. At their optimum temperature of $37^{\circ} \mathrm{C}$, ALP and ACP showed greatest activity of $4.5 \mathrm{KAU}$ and 7 KAU respectively. This was expected because at the optimum temperature, the enzyme has its greatest catalytic activity. As compared to the rate of activity in the absence of enzymes of 1.4 $\mathrm{KAU}$, the activity values obtained in the presence of enzyme show threefold increase. This supports the theoretical principles of enzymes being biocatalysts that speed up chemical reactions [8].

However, the activity of both enzymes is low as compared to previously reported results [9].
Previously, acid phosphatase activity was determined by performing p-nitrophenyl phosphate assay (pNPP) of the bacterial broth culture and the optimum activity was observed at $48 \mathrm{~h}$ of incubation $(76.808 \mathrm{U} / \mathrm{ml})$ and temperature of 45 . In another study, the crude alkaline phosphatase activity of the strain was found to be of $93.7 \mathrm{U} / \mathrm{ml}$ [10]. Difference in the current and previous results could be due to different conditions used such as temperature and time of incubation. Also, the phosphatases from the previous study were obtained from bacteria. These previous results showing high activity explains that there is need to purify the currently obtained enzymes so as to increase their activity and hence and may be of use in industry, agriculture and biotechnology.

In this current study, ALP and ACP showed an increase in the rate of reaction as the enzyme concentration increased as shown in figure 2 . Increase in enzyme concentration resulted in an increased number of enzyme units hence more active sites available at any time to hydrolyze the substrate. The more the enzyme units available at a time the more the products formed thus an increase in the phenol concentration liberated as enzyme concentration increased [11]. Moreover, when substrate concentration was increased whilst keeping other variables constant, the rate of reaction increased as shown in figure 3 .

\section{Conclusion}

Aspergillus niger secretes extracellular enzymes which can be harvested and used in the biotechnology industries. The enzyme of interest was successfully isolated and showed activity. 
Zharare et al., Int. Ann. Sci.; Vol. 9, Issue 1, pp: 41-45, 2020

Increase in the enzyme resulted in increase in rate of activity and increase in substrate concentration resulted in increase in rate of activity. However, the enzyme activity may be increased by purifying the enzyme. Thus, further work is required, such as enzyme purification before the enzyme is marketed in different industries.

\section{Declarations}

\subsection{Acknowledgements}

The sponsors of this work (Department of Biochemistry, University of Zimbabwe, and the University of Zimbabwe Research Board).

\subsection{Funding source}

This study was sponsored by the Department of Biochemistry at the University of Zimbabwe, and the University of Zimbabwe Research Board (Harare, Zimbabwe) is also acknowledged.

\subsection{Competing Interests}

The authors report no conflicts of interest. The authors alone are responsible for the content and writing of the paper.

\section{How to Cite this Article:}

T. Zharare and R. Mangoyi, "Isolation and Activity Determination of Enzyme Phosphatase Secreted by Aspergillus niger", Int. Ann. Sci., vol. 9, no. 1, pp. 41-45, Nov. 2019. doi:10.21467/ias.9.1.41-45

\section{References}

[1] M.K.M. Engqvist and K.S. Rabe, "Applications of Protein Engineering and Directed Evolution in Plant Research" Plant Physiol, 179, 3, 907-917, March, 2019.

[2] R. Sindhu, P. Binod, B.U. Sabeela, A. Amith, K.M. Anil, M. Aravind, R. Sharrel and P. Ashok, "Applications of Microbial Enzymes in Food Industry" Food Technol. Biotechnol, 56, 1, 16-30, January 2018.

[3] D.L. Brautigan and S. Shenolikar, "Protein Serine/Threonine Phosphatases: Keys to Unlocking Regulators and Substrates" Аппи Rev Biochem, 87, 921964, June 2018.

[4] D. Prajapatia, K.D.S.N. Patil and S.V. Chaudhari, "Alkaline Phosphatase: Significance In Dairy Industry" Inter J Res Sc Manage, 4, 12, 18-22, December, 2017.

[5] T. Ezawa and K. Saito, "How do Arbuscular mycorrhizal fungi handle phosphate? New insight into fine-tuning of phosphate metabolism" New Phytol, 220, 4, 1116-1121, April, 2018.

[6] B. Iyer, M.S. Rajput S. Rajkumar, "Effect of succinate on phosphate solubilization in nitrogen fixing bacteria harbouring chick pea and their effect on plant growth" Microb Res, 202, 43-50, September 2017.
[7] R. Koncki, D. Ogończyk and S. Głąb, (2005).” Potentiometric assay for acid and alkaline phosphatase" Analytica chimica acta, 538, 1, 257-261. April, 2005.

[8] P. Robinson, "Enzymes: principles and biotechnological applications" Essays Biochem, 59, 1-41, November, 2015.

[9] B.C. Behera, H. Yadav, S.K. Singh, R.R. Mishra, B.K. Sethi, S.K. Dutta, H.N. Thatoi, "Phosphate solubilization and acid phosphatase activity of Serratia $s p$. isolated from mangrove soil of Mahanadi river delta, Odisha, India” Jour Genetic Engin Biotech, 1-10, January, 2017.

[10] B.C. Behera, H. Yadav, S.K. Singh, R.R. Mishra, B.K. Sethi, S.K. Dutta, H.N. Thatoi, "Alkaline phosphatase activity of a phosphate solubilizing Alcaligenes faecalis, isolated from Mangrove soil" Biotech Res Inno, 1, 1, 101-111, December 2017.

[11] D. L. Purich, "Enzyme kinetics: catalysis \& control: a reference of theory and best-practice methods" Elsevier, $1-4,2010$.

Publish your books with AIJR publisher-

$\checkmark \quad$ Publish with ISBN and DOI.

$\checkmark \quad$ Publish Thesis/Dissertation as Monograph.

$\checkmark \quad$ Publish Book Monograph.

$\checkmark \quad$ Publish Edited Volume/ Book.

$\checkmark \quad$ Publish Conference Proceedings

$\checkmark \quad$ Retain full copyright of your books.

Submit your manuscript at books.aijr.org

\section{Publish your research article in AIJR journals- \\ $\checkmark \quad$ Online Submission and Tracking \\ $\checkmark \quad$ Peer-Reviewed \\ $\checkmark \quad$ Rapid decision \\ $\checkmark \quad$ Immediate Publication after acceptance \\ $\checkmark \quad$ Articles freely available online \\ $\checkmark \quad$ Retain full copyright of your article.}

Submit vour article at journals.aijr.in 